\title{
Introduction to the special issue: In memoriam Stephen Knack
}

\section{Philip Keefer ${ }^{1} \cdot$ Christopher Kilby $^{2}$}

Published online: 3 May 2021

(c) The Author(s), under exclusive licence to Springer Science+Business Media, LLC, part of Springer Nature 2021

Keywords Steven Knack · Collective action problem · Social capital · Trust · Political economy of development · Foreign aid · International organizations

JEL Classification D72 $\cdot$ F35 $\cdot$ F53 $\cdot$ H84 $\cdot$ O15 $\cdot$ O19 $\cdot$ O22 $\cdot$ O43

Stephen Knack (1961-2019) was a valued and cherished member of our scholarly community. Steve first attended the annual Political Economy of International Organizations (PEIO) conference in 2009 when it was hosted in Washington, DC by Georgetown University and joined the board of the Review of International Organizations in 2013, lending his considerable scholarly prestige to the journal. Steve continued to be an important member of the PEIO/RIO community, participating in myriad ways and always generous with his time and gentle with his critiques. In the review below, it should be evident how many young scholars Steve helped to launch.

When news of Steve's untimely death reached the PEIO board, we knew the least we could do was to devote a special issue of RIO to papers that build on Steve's legacy. In keeping with Steve's high standards, we prioritized high-quality scholarship that makes a significant contribution to the field while building, sometimes directly and sometime indirectly, on the foundational work Steve contributed throughout his career.

\section{Responsible Editor: Christopher Kilby.}

Author contributions to research design and conceptualization: P.K. (50\%), C.K. (50\%); writing: P.K. (65\%), C.K. (35\%). The order of authors is chosen alphabetically.

Christopher Kilby

chkilby@yahoo.com

Philip Keefer

pkeefer@iadb.org

1 Inter-American Development Bank, 1300 New York Avenue, N.W., Washington, DC 20577, USA

2 Villanova University, 800 Lancaster Ave, Villanova, PA 19085, USA 
This introduction is divided into two parts. It starts with a necessarily wide-ranging retrospective of Steve's many contributions written by Phil Keefer, Steve's long-time friend, frequent collaborator, and, in many ways, intellectual partner. We hope and believe this retrospective serves two purposes. For people who know and value Steve and his work, it serves as a unique essay that pulls together the many strands of Steve's research, allowing one to see connections that might not be initially apparent and to better understand Steve's intellectual journey. For those who have read only selected articles of Steve's that overlap with their own research, this synthesis may provide a glimpse of the intellectual foundations of work on the political economy of development, the political economy of international organizations, and foreign aid, and, we hope, lead them to look deeply into Steve's many contributions.

The introduction's second (and distinctly shorter) part connects each of the contributions in this special issue to Steve's work and to each other. Christopher Kilby penned these summaries, after serving as the special issue editor.

\section{Institutions, collective action and economic development: The intellectual legacy of Stephen Knack}

Steve Knack devoted his academic life to the most important question of the social sciences: why is economic prosperity the privilege of so few countries? His prodigious research brought deep insight and astonishing creativity to two answers to these questions: Douglass North's (1981) argument, that development depends on the degree to which countries can sustain institutions that lower the transaction costs of economic investment and exchange, and Mancur Olson's (1965, 1982), which identified citizens' ability to act collectively as a central challenge of development. Steve's attraction to these ideas was not a coincidence. The United States Agency for International Development had concluded that these profound insights needed to be brought into the mainstream of development policy and supported the founding of Mancur Olson's IRIS Center at the University of Maryland to advance institutional reform in developing countries. Steve was a student of Mancur's and one of the first researchers to work for the Center.

In the late 1980s and early 90s, the ideas of North and Olson were firmly entrenched, competing for scholarly and policy maker attention with a plethora of complementary hypotheses about how countries develop, focusing on issues ranging from human capital to geography. Institutional research had not yet managed, however, to demonstrate to scholars and policy makers concerned with development the priority that they should give to institutions and collective choice. Steve's work systematically demonstrated the huge quantitative impact of institutions on economic development and spurred decades of research by dozens of scholars on the inextricable links between the institutional and collective choice agendas.

He began by looking at a basic indicator of collective action: the decision to vote. What prompts citizens to engage in the costly act of voting when their individual action has almost no chance of affecting outcomes if everyone else votes and, specifically, how easily dissuaded are American voters from exercising their civic duty? However, voting is just one, albeit an important manifestation of civic behavior. Hence, it was natural for Steve to turn his attention to such behavior more broadly. 
He documented significant variation across countries in the willingness of individuals to engage in personally costly civic behavior. This implied that countries should also vary in their capacity to act collectively - for example, because of differing levels of generalized trust in others. In fact, he discovered significant variation and evidence that a high propensity to act civically and to trust others is strongly positively associated with countries' economic development.

But through what mechanisms do collective action failures impede development? Arguably the greatest collective action challenge that societies confront is to sustain the formal and informal rules and norms that organize social, political, and economic relations (North, 1981). Indeed, as Steve discovered, the rule of law and the security of property and contract rights play an outsized role in economic growth and are, in turn, related to trust and civic behavior.

Having quantified the importance of collective action and institutions for economic development, Steve then asked how international assistance for developing countries could promote institutional reform. This is a daunting question, but Steve took advantage of his long career at the World Bank to discover data that could shed light on it. He identified the conditions under which donor assistance improved recipient countries' institutions, as well as collective action dilemmas that undermined donor actions. Ironically, recipient countries themselves could solve problems of donor coordination. However, precisely because weak institutions are part and parcel of their under-development - as Steve's research concluded - recipient country coordination of donors is rare.

This note reviews Steve's contributions but does not pretend to do justice to the full range of his insights and creativity, nor, especially, to trace the important research that his work inspired in other scholars. For example, one of Steve's gifts was to devise new ways to measure difficult concepts. Across the social sciences and in the public policy domain, the measures of institutions and social capital that he discovered are still in wide use, testimony to the lasting value of Steve's insights. Still, the measurement of institutions and societies' capacity for collective action is difficult, entails numerous tradeoffs and often excites controversy. This controversy triggered a large and rich literature that is beyond the scope of this note.

Just as it is more than coincidence that Steve's research interests were drawn to the study of institutions and collective action, it is also more than serendipitous that a chronological review of his research tells a profound and intellectually coherent story. This note therefore starts with his early research on why people vote, moves on to his research on broader questions of civic duty and inter-personal trust, and then to a key mechanism - the quality of institutions - through which collective action contributes to development and finally to the question of what donors can do about institutional reform.

\subsection{Why do people vote?}

All societies must somehow solve the complex collective action dilemmas of their members. For example, how can they ensure the provision of public goods that most improve citizen welfare, including such intangibles as the rule of law, when individuals have strong incentives to free ride on the contributions of others? Dictators dispense with this challenge by substituting their decisions for those of citizens. 
Democracies embrace the challenge, but the first problem they face is itself a collective action dilemma: because no individual citizen believes their preferences over public goods are pivotal, they often prefer to leave the task of collective decision making to others. Hence, even given the opportunity to vote, many - sometimes most - citizens stay home. Especially during the 1990s, starting with his dissertation at the University of Maryland, through his time at American University and extending to the early years of his work at the World Bank, Steve produced a large body of work that helped us understand when and why people vote.

The question is crucial because of the serious implications that non-voting has for the strategies that politicians adopt to attain office. To increase turnout among their likely supporters, politicians do not tend to rely on their advocacy of institutional quality. All citizens benefit from higher quality institutions, not only those of their supporters who have a weak inclination to vote. Instead, politicians respond to this reluctance by offering private or narrowly targeted inducements: clientelist exchanges of private goods for votes or appeals to divisive sectarian or nationalist interests. The more that politicians emphasize such inducements, the greater is the bias in public policy away from the provision of public goods, including institutional quality. Understanding why people vote is therefore key to understanding how democracies function. It is especially important to know whether people vote in response to a fundamental sense of civic duty or whether instead their motivations are more particularistic.

Knack (1992) argues that social norms play a large role in solving the collective action dilemma that confronts voting in the United States. In this paper, Steve finds multiple correlations between turnout and such socially cooperative behaviors as whether individuals respond to the census, participate in parent-teacher associations, or give to charities. Interpersonal pressures - consistent with social sanctions - are also associated with significantly higher turnout.

Such norms are not inevitably associated with democracy, unfortunately. As Knack (1992) notes, alternative motivations to vote include partisan or group loyalties or other special interest norms. They could also include vote-buying or other individually targeted inducements. These narrower motivations do not appear to crowd out the effects of broader social norms in his US data. They appear to loom larger, however, in the context of younger and poorer democracies, making the issue a key one for study of economic development (this is a point of departure for a large literature, including much of Phil's own work, such as Keefer, 2007).

Another way to assess the strength of civic duty is to examine vote behavior in response to changes in the costs of voting, such as those caused by weather or technical innovations in voting rules. In Knack (1995), Steve examined an innovation to reduce citizens' costs of registering to vote and concluded that tying voter registration to driver's license renewals significantly increased voting rates. He revisited the relationship between civic duty and voting in Knack (1994) and found that although rainfall does not significantly reduce turnout in general, it does among those with a low sense of civic duty. ${ }^{1}$

\footnotetext{
1 Gomez et al. (2007), with data from many more elections and greater geographic disaggregation, show that an inch of rain does indeed reduce turnout by one percent, but do not address the interaction with civic duty.
} 
Distortions associated with turnout are amplified if the reasons for the low propensity to vote, or for casting invalid ballots, are not randomly distributed across citizens. This implies that the inducements that politicians make to encourage voting and the voting technologies that they embrace will be strategically selected to favor some voters at the expense of others who have different policy preferences. Knack and Kropf (2003) were at the forefront of identifying such distortions in the context of voting technology, finding that voided ballots were more prevalent in counties with more African Americans and Hispanics, but not when those counties used voting equipment that prevented voters from making the error of selecting too many candidates.

Knack and White (2000) also investigate voting rules and their impact on turnout, finding that election-day registration significantly increases turnout rates among younger people relative to older and of recent non-movers relative to movers - precisely those who were expected to benefit the most from registration reforms. However, it does not increase turnout of any income class relative to others (e.g., the poor relative to the rich) nor of the less- relative to the more-educated.

Knack (1993) also explored reforms that raised the costs of voting. US citizens have the civic duty of serving on juries. American society appears to be under no illusions that citizens have a sufficiently high sense of civic obligation to fulfill this costly duty, however, since state and national laws penalize non-compliance. In 1968, concerns that $\mathrm{ad}$ hoc jury selection practices biased - or were intended to bias - the composition of jury pools led Congress to pass a law that required jury lists be assembled from voter registration data. Steve noticed this and tested whether increased chances of being compelled to exercise one civic duty - jury duty - would reduce citizens' willingness to engage in another - voting. Knack (1993) finds dramatic effects: the prospect of jury duty depressed voter turnout by as much as eight percentage points.

\subsection{Social capital, institutions, and development}

Steve's work began with a focus on voting but rapidly turned as well to the broader challenges of collective action and civic duty, driven by the certainty that voting alone is insufficient to sustain liberal democracy. For example, the regime-type indicator of the V-Dem database (Coppedge et al., 2021) characterizes 87 of 179 countries as democratic in 2019. In all of these, citizens are free to vote, and do vote. Of the 87 , however, only 37 are deemed to be liberal democracies, with institutions that promote collective action by citizens (e.g., protect the right of assembly) or intangible public goods such as the rule of law. The remaining 50 have free and fair elections, but other rights associated with liberal democracy are less in evidence.

Evidently, citizens' sense of civic duty in democratic societies, even if it leads them to vote, is not enough to prompt them to participate in other types of collective action or to contribute to essential public goods. Other evidence amply demonstrates that civic duty is often insufficient to persuade citizens to pay their taxes, to refuse gifts for votes, or to support policies or institutional arrangements that promise to raise social welfare rather than policies that provide them with private rewards at the expense of society generally. 
Steve and Phil both had the good fortune to find themselves, at the very beginning of their careers, at the IRIS Center at the University of Maryland. There they began working together on the relationship between themes of collective action and civic duty, on the one hand, and development on the other. Their point of departure was the burgeoning literature on social capital, beginning with Putnam et al. (1993), which went beyond the decision to vote to focus on variations across societies in civic behavior more generally. The first product of this collaboration turned out to be Steve's (and Phil's) most cited article, "Does Social Capital Have an Economic Payoff?" (Knack \& Keefer, 1997). There, they undertook the first systematic empirical investigation of the relationship between civic behavior and growth.

Key to this work was the realization that certain variables in the World Values Survey precisely captured concrete aspects of the somewhat fuzzy concept of social capital. One set of variables allowed them to characterize civic norms, yielding an index of respondents' beliefs about how often it could be justified to engage in such behavior as claiming government benefits to which they are not entitled. However, while civic norms are essential to civic behavior, so also is confidence that others in society exhibit those norms. A reasonable proxy for this belief is trust in others: in high trust/more trustworthy societies, citizens are more likely to believe that others will also behave civically. Respondents to the World Values Survey were asked whether they believed that people could in general be trusted, or on the contrary, that one could not be too careful in dealing with others. Taking advantage of these variables, Phil and Steve found that trust and stronger civic norms are in fact associated with higher and more equal incomes per capita.

Their findings, like the earlier work on social capital, raised an important question: through what specific mechanisms do trust and civic norms promote development? North $(1981,1990)$ provided a possible answer: economic growth depends on the formal and informal norms that regulate economic activity. Where the norms are such that individuals face fewer risks that their trading partners will renege on their contractual obligations, or where their investments will be expropriated by other members of society, they will be more willing to invest and innovate. Trust and civic norms affect these risks both directly and indirectly.

The direct effect is obvious: in societies that exhibit stronger civic norms and greater trust, individuals are likely to be less inclined to renege on their contractual obligations or to infringe on the property rights of others. Ample research demonstrates this proposition. In an important piece with Paul Zak, Zak and Knack (2001) present a notable example. They investigate the relationship between trust, growth, and investment in a general equilibrium growth model that allows economic agents to expend resources in verifying the truthfulness of claims made by other agents. In high trust environments, these expenditures are lower, raising the returns to investment; consistent with the theory, capital investment and growth are correspondingly higher in high trust countries.

The indirect pathway is at least as essential. As North emphasized, the rules under which government regulates the economy and mediates disputes shape incentives to invest and exchange. Even in high-trust societies, third party institutions are necessary to adjudicate conflicts between economic actors. However, support for third party institutions and welfare-improving government regulation 
are ultimately decisions of citizens and are acutely subject to the collective action dilemma. Any individual member of society stands to gain by offering a bribe to escape a regulation, threatening a judge to escape prosecution, or building on the property of others without paying for the right. Collectively, however, all are better off when societies make investments to discourage this behavior. As Olson $(1965,1982)$ argued, the collective action dilemma that confronts societies tends to disfavor government decisions and institutions that support economic growth; instead, the failure to solve the dilemma allows special interests to distort public policy in their favor, at the expense of broader growth.

Until the early 1990s, no systematic empirical evidence had emerged of either segment of this indirect pathway, neither from society's capacity for collective action to institutions nor from institutions to growth. In their very first collaboration, encouraged - inspired - by Mancur Olson and Chris Clague at the IRIS Center, Steve and Phil presented the first empirical test of North's claims regarding the second segment, the importance of secure property rights for economic growth (Knack \& Keefer, 1994). The key to this work was Steve's discovery that foreign investment advisory services produced expert ratings of four key institutional characteristics of countries: the rule of law, contract enforcement, the risk of expropriation, and corruption. The advisory services sold these data to multinationals and other clients, offering a market test of their validity. In this early work, Knack and Keefer (1995) established that the indicators were strongly associated with growth and investment and that the association remained strong after controlling for indices of democracy and political violence.

In Keefer and Knack (1997), they then brought the data to a central puzzle: why do poor countries not grow faster than rich countries, when neo-classical growth theory predicts that countries with lower levels of capital and technology should exhibit higher returns to both? The answer they found was that convergence depends on the institutional environment. Where property rights are secure and the rule of law prevails, poor countries do, in fact, converge with rich countries. However, large average differences in institutional quality between poorer and richer countries lead to large and persistent divergence between the two groups.

These papers linking institutions to economic development triggered a large body of research concerned, ostensibly, with the issue of identification: how do we know that unobserved characteristics of countries with stronger rule of law and greater respect for property rights are not driving the association between these and growth? The identification concern yields a deeper and more interesting question, however: what are the origins of strong institutions? If they emerge from social, political, and historical circumstances that simultaneously influence economic development, then the association of institutional strength and growth is simply a happy by-product of those circumstances, but not an indication of a causal relationship between them.

Efforts to address either variant of this question have been significant and will continue. They began with the publication of the remarkable research of Acemoglu et al. (2001). This work addressed the identification problem, verifying that the results that Phil and Steve's research uncovered indeed had a causal interpretation, with a significant substantive claim, that strong institutions have deep historic roots. In the contexts 
Acemoglu et al. (2001) and other authors investigate, historic circumstances appear to constitute excludable instruments, affecting growth only through their impact on institutions. And it appears that they are strong instruments: historic circumstances account for a large share of institutional variation across countries.

What about the first segment of the indirect path from societies' capacity for collective action, via institutional quality, to growth? Is it true that societies that exhibit greater capacity for collective action exhibit higher institutional quality? The historic evidence in Acemoglu et al. (2001) hints at the possibility, though it does not feature in their analysis. All types of economic transactions, including those entailed by collective action, benefit from the prospect of repeated interaction. Collective action is therefore more likely when members of a society have long horizons. The high rates of settler mortality that suppress contemporary institutional quality in Acemoglu et al. (2001) were likely inconsistent with long horizons.

Steve's work also uncovered evidence of a link from collective action to institutional quality. Already in Knack and Keefer (1997), Phil and Steve found that trust and civic norms are higher in countries with political arrangements - restraints on the chief executive of a country - that raise institutional quality, by restraining such predatory actions as expropriation. They went on to explore whether societal characteristics that might make trust and civic norms harder to sustain were also associated with lower institutional quality.

One such characteristic is social polarization, whether because of inequality or ethnic or religious division. If polarized societies find it more difficult to act collectively, then they should also be less likely to provide a key public good - secure contract and property rights. Knack and Keefer (1997) show that trust and civic norms are stronger in more ethnically homogeneous countries. In work that began while they were together at the World Bank, Steve and Phil argued that polarized societies are more likely to abandon the institutional arrangements that facilitate collective choice in a country (Keefer \& Knack, 2002). They document that three sources of social polarization - income inequality, land inequality, and ethnic tensions - are all associated with weaker contractual and property rights and, moreover, that the negative relationship between inequality and growth is significantly attenuated after controlling for institutional quality.

Another methodological line of research triggered by Knack and Keefer (1995) and Keefer and Knack (1997), apart from the literature on identification and history, concerns measurement. The quality and interpretation of measures of institutional quality preoccupied Steve throughout his career, from the IRIS Center at the University of Maryland to the World Bank. When set against the benchmarks of quantitative assessment in labor or health economics, the challenge of institutional measurement is obvious. We hesitate to assess the success of a country's education policies through subjective assessments of student learning or of its health systems through subjective assessments of patient wellness. Compared to measures of institutional quality, however, it is easier in these sectors both to conceptualize and to implement objective measures of treatments and outcomes. In the case of institutional quality, in contrast, hundreds of researchers have analyzed institutions using subjective assessments because objective variables are almost entirely absent. In their absence, 
scholars have reasonably sought to make intellectual progress by relying on the next best indicators.

Steve and co-authors nevertheless labored to come up with objective substitutes for foreign investment risk assessments. One result of this effort was "contractintensive money," developed by Mancur, Chris, Steve, and Phil at the IRIS Center (Clague et al., 1999). Elements of a country's money supply differ in the confidence that they demand of users in a country's institutions. Holding and using cash requires less reliance on contract and property rights enforcement than do longer-term deposits in a country's financial institutions. Countries with a more secure institutional environment should therefore exhibit a higher share of "contract-intensive" money in the total money supply. Consistent with this argument, contract-intensive money significantly predicts income, growth, and investment.

This measure proved to be both plausible and tractable and was subsequently taken up by other researchers. Nevertheless, the advantages of objectivity and precision were not enough to shift the bulk of institutional research away from reliance on the subjective measures produced by foreign investment risk advisory firms. Economists and political scientists, in a striking display of revealed preference, largely continued to use noisy, but ostensibly more direct, measures of institutional concepts rather than more precisely, but indirectly measured proxies.

Policy makers, working through international organizations, also exhibit such a preference. For example, the World Bank regularly reviews countries' eligibility for non-concessionary IBRD (International Bank for Reconstruction and Development) loans. Eligibility should depend in part on Bank judgments about countries' institutional quality. Knack et al. (2012) confirm that, controlling for income and other variables, countries are indeed more likely to graduate if they exhibit higher scores on foreign investment advisory assessments of institutional quality. The World Bank does not rely on such external assessments in judging institutional quality, instead using its own internal - but also subjective - assessments.

During his long career at the World Bank, Steve made significant contributions to improving the quality and consistency of these internal assessments. At the same time, he regularly pointed out the hazards of over-interpreting subjective indicators or aggregations of indicators that claimed to distinguish between institutions that control corruption, maintain the rule of law, or protect contract and property rights. Both in the academy and in policy circles, the push for measurement of institutions has been driven by a need for actionability and to capture precise theoretical mechanisms. Policy makers seek specific levers that they can pull to improve institutional quality; analysts seek to test quite distinct institutional theories (e.g., those that yield testable hypotheses about corruption or property rights) and, for that purpose, need measures that capture the specific theoretical concepts (i.e., corruption, but not insecure property rights). Steve and his co-authors, in many analyses both published and internal to the Bank, cautioned that individually or aggregated into indices, subjective indices do not lend themselves to narrow and exclusive interpretations (e.g., Knack, 2007; Langbein \& Knack, 2010). 


\subsection{International organizations, institutions and development}

Given the importance that Steve's research assigned to institutions and social capital in the development process, it is perhaps not surprising that during his long career in the World Bank he made substantial contributions to research on the relationships among international aid, institutions, and growth. Two broad themes characterized this research: does international aid improve the quality of institutions? And does the organization of aid - the fragmentation of donors - affect aid impact?

Knack (2001) and Bräutigam and Knack (2004) undertook two of the first analyses focused on the first question, the relationship between institutions and foreign aid. Donors confront a dilemma: on the one hand, foreign aid can allow countries to accelerate the pace of institution-building; but in countries with weak institutions, foreign aid can have the opposite effect if recipient governments deploy it instead to support rent-seeking or to postpone the strengthening of their own revenue-raising capacity. Which tendency prevails?

The papers do not conclude with grandiose causal claims, but they nevertheless uncover robust and uncomfortable associations in the data. For example, high levels of aid in Africa are significantly correlated with subsequent deteriorations in an index capturing corruption in government, bureaucratic quality, and the rule of law, and with a decline in taxes as a share of GDP. These persist after controlling for multiple additional factors that should influence institutional quality, including initial institutional quality, income per capita, and political violence; and, in the case of robust negative correlations between aid and the share of taxes in GDP, controlling for initial tax shares. Another indicator of institutional quality is the quality of tax systems. Again, Steve found, in Knack (2009), that sovereign rents are associated with lower quality tax systems, whether those rents are the product of foreign aid or of natural resource dependence.

The negative correlations between aid and institutions do not appear to arise because aid triggers fundamental changes in accountability relationships between citizens and government. In Knack (2004), Steve finds no effect of aid on democracy, regardless of the measure of aid or the measure of democracy, nor inclusion or exclusion of the Cold War period from the estimates. Fifteen years later, in de la Cuesta et al. (2019) Steve and co-authors conducted four experiments in Ghana and Uganda and found that individuals demanded as much accountability for government spending when it was financed by aid or oil revenues as when it was financed by taxes.

This research does not exactly provide robust support for the institution-building potential of foreign aid; nevertheless, Steve conducted all his research on aid while at the World Bank. ${ }^{2}$ This fact is remarkable for several reasons. First, it shows Steve's stubborn pursuit of the truth. Second, it speaks to the tolerance of the World Bank for discordant research, something that is not always easy for large, government-owned institutions, but is critical if institutions are to learn and improve their performance.

\footnotetext{
2 Still, in one of Steve's last papers on aid effectiveness, Galiani et al. (2017) look at the group of countries that crossed the income threshold governing eligibility for IDA lending, and which consequently experienced a significant decline in aid. They find a large effect of aid on growth (a one percentage point drop in aid reduces GDP growth by 0.35 percentage points).
} 
Third, neither Steve nor the World Bank (nor, for that matter, Phil, during his own time at the World Bank) left this work on a dusty shelf. They instead renewed efforts to find more compelling entry points and better strategies for public sector reform. The imperative for this is clear: it is difficult to envision successful economic development in the presence of weak institutions, as difficult as it may be to strengthen them.

Steve's work was concerned not only with the impact of foreign aid on recipient country institutions, but also on the effect of donors' own collective action problems on the impact of aid. Their collective action dilemma is significant: the donor country's public is likely to offer greater support for aid when the aid is not wasted and when the donor's aid agency can take credit for better outcomes. ${ }^{3}$ Many development obstacles, however - with low-quality institutions perhaps the most important among them - are a difficult challenge for donors collectively, but certainly for any donor individually. Through an ambitious program of research, Steve documented the importance of the collective action dilemma for donor effectiveness, challenging other narratives that emphasized, for example, the possibility that fewer donors could more easily collude against the interests of recipient countries.

Knack and Rahman (2007) describe one concrete collective action problem, related to the hiring practices of donors. The in-country management of donor projects requires skilled professionals who, in aid-dependent countries, tend to be in government. When donors hire away government officials to manage their projects, they potentially reduce the quality of government institutions. However, when there are many donors, no single donor's hiring practices have a large effect on country institutions. Individually, therefore, donors have no reason to impose restraints on those practices.

The situation mirrors Hardin's (1968) tragedy of the commons. However, as Ostrom (1990) observes, the tragic outcome of over-predation occurs only if the actors involved (in this case, donors) cannot solve their collective action problem. In fact, Knack and Rahman (2007) find that they cannot. They replicate findings from other research showing that higher aid levels are associated with declines in bureaucratic quality in recipient countries. However, even controlling for aid levels, they find that greater fragmentation among donors is also strongly associated with declines in bureaucratic quality.

Donors' collective action challenges go far beyond hiring. Another relates to the decision of donors to allow countries to rely on their own fiduciary systems for managing donor funds or instead to require them to use donor systems. These systems are essential nuts and bolts of a country's institutions: they are how the public sector controls corruption and ensures the rule-based expenditure of public funds. As a group, donors face a familiar tradeoff. To the extent that reliance on own systems gives recipients an opportunity to strengthen those systems, the first strategy therefore better supports donor objectives to build institutions. The first strategy is less desirable, however, to the extent that it allows greater diversion and waste of donor

\footnotetext{
3 Indeed, Paxton and Knack (2012) find that popular support for foreign aid in donor countries is greater among more religious and trusting individuals - and correspondingly lower, therefore, among those who are more inherently skeptical that foreign aid is well-used.
} 
funds. The tradeoff is more acute the worse are country systems, so if recipient countries have only a single donor, we expect that donor to rely on country systems when their quality is above a certain threshold.

However, most recipient countries have multiple donors. They confront, in addition, a collective action dilemma. When there are many donors, no single donor can have a significant influence on institution-building by relying on recipient country systems. In contrast, a single donor incurs the full costs of waste and diversion that such reliance might occasion. Hence, in equilibrium, the larger the number of donors, the less we should observe that they rely on recipient country systems.

In Knack (2013, 2014), Steve explores these issues and finds support for both hypotheses. First, donor willingness to rely on recipient country systems is greater where the quality of those systems was higher. When country systems are weak, donors have relatively little confidence in the institution-building potential of reliance on country systems and relatively large concerns about the risks of misuse of donor resources. Hence, they rely on country systems only when they are more robust. Second, though, he finds that donors were more likely to rely on recipient country systems when the donors provided a larger share of total aid to the recipient. $^{4}$

The most extreme example of donors free riding on the development efforts of other donors is the practice of tying aid to recipient purchases of goods and services from the donor country. Knack and Smets (2013) find strong evidence that aid tying is indeed more pronounced when donors have the greatest incentives to free ride - when fragmentation is high.

One way that bilateral donors can solve their collective action dilemma is to delegate aid decisions to a multilateral organization. Annen and Knack (2018) observe that this delegation is significant: bilateral donors transfer significant resources to multilaterals for them to manage in "trust funds." They discover a puzzle in this delegation decision, though, upon examining the allocation decisions of bilateral and multilateral donors across policy areas. Multilateral allocations overlap significantly with the average allocation decisions of the bilateral donors. Given this overlap, what drives delegation? The answer that they give is that bilateral donors struggle to come to agreement on which countries to prioritize. That is, while donors can act collectively to direct resources to priority policy areas, they are less able to resolve disagreements regarding country priorities. By delegating decision making to multilaterals, they attenuate this collective action problem.

Steve's research with other co-authors revisited this logic. In Reinsberg et al. (2017), he and co-authors present evidence that bilateral donors are more likely to participate in large, multi-donor trust funds managed by multilaterals when their policy preferences are aligned. Eichenauer and Knack (2018) also explore the tensions

\footnotetext{
${ }^{4}$ Gehring et al. (2017) provide evidence supporting some of the mechanisms underlying this collective action problem. First, donor fragmentation should matter less when one donor internalizes the costs of overcoming the collective action problem. They find, correspondingly, that donor fragmentation reduces growth only in the absence of a lead donor. Second, recipient countries themselves could coordinate donors, but only if they have sufficient capacity to do so. Again, consistent with this, they find that the negative effects of fragmentation disappear when recipient countries have greater administrative capacity.
} 
that arise in the management of donor trust funds by multilateral agencies, when the two parties have different objectives. They find that trust funds that have many contributors have allocation criteria similar to the World Bank's (strictly speaking, those of the International Development Association or IDA, responsible for allocation criteria for lending to poor countries). In contrast, the trust funds financed by single donors are more related to the strategic interests of the specific donors. Still, we would not expect the multilateral organization to accede to the management of a trust fund with goals at odds with its own and, in fact, as in Annen and Knack (2018), they conclude that all trust fund criteria are largely compatible with IDA criteria.

Much of the development literature, and of Steve's work discussed above, considers the aggregate influence of institutions. However, institutions are the product of organizations and the choices made by the individuals inside those organizations. In general, Steve's work did not delve into the internal workings of institutions - those that are responsible for the rule of law or for restraining corruption, for example. But he did investigate two decisions of donor organizations: how to allocate aid, and how much aid to give.

In the late 1990s and early 2000s, donors such as the World Bank announced a significant shift in aid allocation toward making them contingent on the quality of recipient country policies. Annen and Knack (2019) ask whether donors followed through on these announcements. They find that, indeed, the shift in aid strategies was large and significant. ${ }^{5}$ Donors also have important decisions to make regarding the rigor with which they design aid programs and supervise their implementation. In Smets et al. (2013), Steve and co-authors take a unique approach to this question. They argue that the partisan orientation of a government affects its willingness to implement economic policy reforms and, consistent with their model, find that the quality at entry of World Bank economic policy loans is higher when left wing governments are the borrowers and these governments are more likely to succeed.

With respect to the second decision, in Dang et al. (2013), Steve and his coauthors find that donor altruism is highly elastic with respect to donor income. Specifically, aid drops significantly after donor country banking crises. They calculate that banking crises reduced aid by more than 30 percent - notable not only for its magnitude, but also for the fact that the impact was greatest 10 years after the crisis, well after donor economies had recovered.

\subsection{Conclusion}

Steve's family and friends, faced with the deep sadness of his untimely death, treasure our memories of a wonderful person. The scholarly community, too, though

\footnotetext{
5 Of course, the point of this shift was to prompt recipient countries to pursue better policies. Annen and Knack (2019) find some positive incentive effects on recipient countries, as do Smets and Knack (2016). This suggests potential improvement in donor effectiveness since, years earlier, Steve and Jac Heckelman found that foreign aid had no significant effects on measures of economic policy broadly described as "economic freedom" (Heckelman \& Knack, 2009).
} 
deprived of the light that Steve's insight cast on difficult problems, still benefits from the legacy of his research and the directions for future research to which it points. What objective markers distinguish countries with high and low institutional quality? What collective decisions allow countries to improve those institutions? How can we support the capacity of countries to overcome their collective action dilemmas and improve institutional quality? These are important, difficult questions. However, the progress that Steve made in uncovering answers to them can give us confidence that "difficult" does not mean "intractable." On the contrary, his example signals that future research on these issues should be both feasible and rewarding.

\section{Contributions to the special issue}

The eight papers that make up the research contributions to this special issue cover a wide range of topics at the forefront of research on the political economy of international organizations and foreign aid. Just as Steve's work started with basic questions and led to specific explorations of the implications of those questions, the contributions below draw on new theories, new ideas, and new data to better explore questions raised by past research.

In a classic contribution to the development literature more than 40 years ago, Judith Tendler (1975) explored the paradox of the "abundance of development assistance," how aid could be scarce but allocated as if it were abundant. In this special issue, Carnegie and Dolan (2021) explore a similar paradox, though with very different roots: disaster-stricken countries rejecting offers of aid. Carnegie and Dolan argue that status-seeking governments may reject offers of aid when doing so sends a credible signal of competence to enhance their status as a self-sufficient state. This signal is more credible coming from governments with more competence and resources; the strength of their desire for status is also a factor. The authors develop a game theoretic model to formalize this idea and more fully develop its empirical implications. Since their argument is predicated on the claim that whether or not a state accepts international aid impacts international opinion about the state (i.e., its status), Carnegie and Dolan conduct a survey experiment to test this claim for U.S. respondents. The survey uses a natural disaster in India as the example, informing the treatment group that the Indian government rejected aid. Responses capturing participants' assessment of the Indian's government's competence are significantly higher (statistically and quantitatively) for the treatment group that knew aid had been rejected. With the premise of their model validated, Carnegie and Dolan turn to testing the implications of the model by examining under what circumstances governments are more likely to reject offers of disaster assistance. Measuring the government's own capacity to respond via the country's GDP (relative to the severity of the disaster) and its interest in international status via its military spending (or UNSC ambitions), the authors find clear evidence that more capable and more ambitious governments are less likely to accept aid.

As in Knack (2013), the authors focus on how international perceptions of the recipient government help shape the aid that a country receives. In Steve's work, it is donor trust in country systems that shapes aid flows. Carnegie and Dolan step back 
further and ask whether international perceptions might even influence whether a country's government accepts offers of aid. Looking at the literature on the political economy of international organizations more broadly, this contribution explores the role of aid in shaping international perceptions of a country and argues that the desire to improve its international standing may lead a government to reject offers of needed relief aid.

While foreign aid (for disasters or otherwise) may be given to improve people's lives, there have long been concerns about potential unintended negative consequences. Steve's work highlighted some of these, such as the impact of foreign organizations on government bureaucratic quality in aid-dependent countries (Knack, 2001; Bräutigam \& Knack, 2004; Knack \& Rahman, 2007). As donors focus on the success of the projects they fund and hire the best local talent to do so, they may distort the local labor market by offering salaries that are inflated by local standards. This can draw qualified bureaucrats away from the government and thus do more harm than good. Thus, aid-like oil-may skew prices such that other sectors of the economy fail to develop. Some argue that both oil and aid may also distort the relationship between the government and the governed, providing non-tax revenue and thus making the government less dependent on (and thus responsive to) taxpayers.

This is the starting point for de la Cuesta et al. (2021), who note that there are theoretical arguments for and against the claim that aid receipts act like oil revenue in reducing government accountability. ${ }^{6}$ The arguments of aid skeptics are outlined above. For aid enthusiasts, donor conditionality (i.e., the threat to withhold future aid if current aid is misappropriated or if promised reforms fail to materialize) and citizen expectations that aid should fulfill its mandate to improve their lot distinguish aid resources from oil revenue and hold out the promise that aid can accomplish more.

De la Cuesta and coauthors focus on accountability to citizens and report the results of a series of six field experiments in Uganda and Ghana-both countries where citizens have extensive experience with foreign aid and with oil revenue. The experiments explore whether aid and oil elicit different responses with regard to political accountability. Results across all six field experiments are consistent, finding no significant differences in responses capturing political accountability when comparing aid to oil. Looking beyond statistical significance, effect sizes are extremely small, suggesting this is not an issue of statistical power but rather a substantively important finding. These results are consistent with Knack's (2004) seminal finding that aggregate aid flows do not have a significant effect on democracy. ${ }^{7}$ The results presented by de la Cuesta and coauthors convincingly argue that if the impact of aid on democracy differs from that of oil, it must be through a different channel such as donor conditionality.

\footnotetext{
6 This study builds on an earlier study to which Steve contributed (de la Cuesta et al., 2019).

7 Knack (2004) has sparked significant research exploring the impact of aid on democracy. While many studies confirm Steve's null result, others, using different samples, estimation methods, and measures of democracy, have found different results.
} 
As discussed above, a good part of Steve's work on foreign aid questioned comfortable assumptions about the beneficial impact of foreign aid. While some assume that aid must be accomplishing its purpose and so more aid is necessarily better, in numerous papers Steve insisted on looking at the empirical evidence. The foundation of this skeptical approach was a focus on incentives and concerns that aid flows could distort incentives and lead to perverse outcomes-at least in some cases. Steve's work on aid and the quality of governance (Knack, 2001; Bräutigam \& Knack, 2004) is perhaps the clearest example of this and highlights the possibility that donor money can lead to distortions that ultimately undermine aid's ability to benefit recipient countries.

Harris (2021) follows in this tradition and explores an important new dimension: education. Harris argues that the priorities of aid donors-priorities that align poorly with private sector skills needs — can play an important role in shaping both the offerings in colleges and universities in aid-dependent countries and the choices made by students when selecting their course of study. Drawing on detailed data from Sierra Leone in the years following its civil war, Harris demonstrates that the country is relatively well-supplied with students trained in fields like development management, conflict resolution, and peace and conflict studies, credentials thought attractive to local and international NGOs. Graduates with STEM degrees in demand by local industry, however, remain in short supply. These findings complement Steve's work twenty years before that examines how donor demand for local staff can draw talent away from other parts of the labor market. In Steve's case, the result is lower government bureaucratic quality in aid-dependent countries; in Harris' case, it is a deficiency in the skilled labor force needed for domestic industry, a far more fundamental driver of long run economic development than the NGO sector.

Another aspect of aid that has received considerable attention is its volatility and the potential negative effects of that volatility (specifically large, sudden drops in aid flows). Gamso et al. (2021) examine how this intersects with another important topic in studies of foreign aid, the link between aid and migration. The impact of aid on migration has been hotly debated. If aid improves conditions in recipient countries, it should reduce the economic incentive to migrate. However, in the presence of significant credit constraints, the limiting factor on migrant flows could be the upfront costs of migration, in which case aid resources may allow more workers in the aidreceiving country to afford the cost of migration. The impact of aid volatility is perhaps more obvious; while the positive effects of large, sustained aid flows over time may be debated-because of negative effects on local bureaucracy (Knack, 2001) and political accountability (de la Cuesta et al., 2021) — most agree that a sharp, unexpected drop in foreign aid flows will disrupt the recipient economy in a number of ways.

Gamso and coauthors argue that negative aid shocks will lead to reduction in the government services upon which low skill workers depend, but which generally do not benefit medium and high skill workers. If enough lower skill workers have the means to migrate, negative aid shocks should trigger increased out-migration. Thus, it is empirically plausible that aid volatility is associated with increased migration, the question that this paper investigates using aid and migration data for 100 
countries over a twenty year period. The patterns in the migration data support the authors' conjecture, both in terms of the direction of the effect (negative aid shocks are followed by increased migration) and in terms of who migrates (low skill workers who are more likely to be directly impacted by a reduction in government services).

The current focus on aid to stem migration might draw some important lessons from this work. The first is most obvious: sharp cuts in aid will likely cause a flow of low skill migrants so attempting to strong-arm developing country governments to stem the flow of migrants by slashing their aid could well prove counterproductive. Second, we might learn what types of aid reduce migration by observing spikes in migration in response to sudden cuts in that type of aid.

While aid volatility has been an important question in the quantitative literature for the last 20 years, questions about the impact of IFI lending on the poor date from at least the debt crisis of the 1980s. A 1985 UNICEF booklet argued for "adjustment with a human face" and effectively accused the IMF and the World Bank of being baby killers based on differences between infant mortality rates in countries undergoing Fund/Bank adjustment and other countries. Since countries are not randomly assigned to adjustment programs, such rough with-and-without comparisons are unlikely to provide an accurate assessment of the true impact of these programs. Over the years, the literature has struggled with this issue. The questions scholars ask have broadened and methodological advances to address selection on unobservables have been applied incrementally (see, for example, Vreeland (2002), which focuses on the impact of IMF programs on inequality). Nonetheless, questions about causal identification persist and have, in effect, provided cover for these institutions even as they have changed and adapted their approaches to crisis management and structural adjustment.

Against this backdrop, Lang (2021) again asks what impact IMF programs have on income inequality in adjusting countries. Lang makes use of better income inequality data and, importantly, advances a novel identification technique based on a shift-share approach that exploits exogeneous variation in IMF liquidity and a country's past record as an IMF client. Early drafts of this article have already inspired other IMF scholars to apply Lang's approach. The paper finds that IMF programs do indeed cause income inequality to increase and Lang is able to pin down the proximate cause: IMF programs (on average) increase income inequality because they reduce the income of the poor (rather than increasing the income of the rich). Effects are sizable and persist for up to 5 years.

The article's title phrase - the democratic deficit—reflects a dimension of heterogeneity in the results. The effect of IMF programs in increasing income inequality are stronger in democracies, where the type of policies implemented might not be feasible without the leverage provided by the IMF; more autocratic governments may have less need for the IMF to play the role of enforcer. The article thus provides an interesting methodological step forward and an important road map for those wishing to reform the institution. As Lang notes, his work follows Knack (2001) in exploring potential adverse effects of international financial assistance and Knack (2004) in exploring the complex interplay between international aid and democracy.

Heinzel and Liese (2021) draw on a very different literature sparked by Steve's seminal work on social capital, trust, and economic growth (Knack \& Keefer, 1997; 
Zak \& Knack, 2001). Heinzel and Liese explore the role of trust and expertise in the success of World Bank projects. Building on earlier work by Steve (Smets et al., 2013) and by other World Bank economists (Denizer et al., 2013; Bulman et al., 2017), Heinzel and Liese use ratings of borrowing government performance to explore how international bureaucrats-here, World Bank Task Team Leaders (TTLs)—influence policy and recipient government behavior. The authors consider three explanations for TTL influence on borrower performance: the TTL's supervisory experience; the intensity with which the TTL enforces rules and procedures; and the degree to which the TTL functions as a sympathetic interlocutor.

To explore these alternate channels, the authors construct an extensive database on TTLs that characterizes them based on their experience at the World Bank. To settle issues of timing that these web-scraped data do not answer, Heinzel and Liese sample project documents in greater depth. After an exhaustive analysis to rule out competing explanations, the takeaway is that TTLs have significant influence on borrower performance for investment projects but not for development policy operations. The evidence is particularly clear for supervisory experience and country-specific knowledge and networks (and thus the ability to serve as a sympathetic interlocutor). Returning to Steve's theme of the importance of trust, it appears TTLs can leverage trusted networks to support borrower performance in World Bank-funded investment projects.

Marchesi and Masi (2021) explore the influence of the World Bank on project outcomes from a different angle. Aid donors face several decisions when designing the administration of projects they fund in developing countries. One key design decision is the degree of delegation. Marchesi and Masi argue that consideration of information asymmetry should play an important role in this decision and that how the donor chooses to administer the project will influence the outcome of the project. Using data for World Bank projects, these authors explore what factors influence the choice between a centralized and a decentralized approach and whether and how that choice influences project outcomes.

Marchesi and Masi argue that greater information asymmetry (especially between local governments and the central government) will exist in countries that are less transparent, because the central government will have less access to hard information needed for project implementation decisions. Because this is a central point of the paper, the authors consider four ways to measure transparency. These include two measures derived from the share of macro data missing from the World Development Indicators, Williams' (2015) “Combined Transparency Index” (which itself draws on a wide range of sources), and the Press Freedom measure from Freedom House. In all cases, the greater the degree of transparency, the less likely project administration is decentralized. Pushing their information story one step further, the authors find that the effect of decentralization (delegation to a local implementing authority) decreases as transparency increases.

The article follows, to some extent, Steve's work on project performance looking at the interplay between societal factors and project characteristics in determining the outcome of World Bank-funded projects (Knack \& Rahman, 2007; Smets et al., 2013). It also mirrors to a degree Steve's work on the delegation of implementation (Annen \& Knack, 2018). Marchesi and Masi, however, cover important new territory in their focus on the informational environment in the borrowing country 
and in considering delegation from the World Bank to various levels in the recipient government, rather than from donors to the World Bank.

Dreher et al. (2021) also build in part on Annen and Knack (2018) and the literature on how multilateral aid agencies may help solve time inconsistency problems that undermine bilateral aid donors' ability to implement conditionality. However, multilateral aid agencies are not fully independent from the governments that fund them and hence the degree to which delegation to a multilateral solves an incentive problem depends on the governance structure of the multilateral.

Dreher and coauthors explore this issue, first by demonstrating empirically that the cross-country allocation of funds by multilateral development agencies that follow a consensus rule for decision making is less sensitive to recipient country bureaucratic quality than the cross-country allocation of funds by multilateral development agencies that follow a majority rule approach. Differences across these two types of institutions are both statistically significant and quantitatively large. The rest of the paper presents a game-theoretical model to explain this difference in lending patterns based on the differing incentive structures created by these two decision rules. The authors focus on key elements, stripping away real-world details that prove irrelevant to the central mechanism and selecting the theoretically toughest case, i.e., where each donor government cares only about a single recipient. The model allows the authors to examine the optimal design of a multilateral in terms of its decision-making structure and highlights the potential trade-off inherent in selectivity, as a more selective allocation will imply that some otherwise high return projects remain unfunded.

The model has potential applications for earmarked multilateral funds (the so-called multi-bi aid), another important area studied by Steve with coauthors (Eichenauer \& Knack, 2018; Reinsberg et al., 2017).

As the first section of this introduction makes clear, Steve Knack's academic contributions covered a wide range of topics and areas. Included in this body of work are numerous foundationally important papers on foreign aid and international organizations. The papers in this special issue draw on Steve's work as they push the frontiers of research on the political economy of international organizations. No doubt Steve's writings will continue to inspire scholars for decades to come.

Disclaimer The findings, interpretations, and conclusions expressed in this paper are entirely those of the authors and do not necessarily represent the views of the Inter-American Development Bank, its directors, or the countries they represent.

\section{References}

Acemoglu, D., Johnson, S., \& Robinson, J. A. (2001). The colonial origins of comparative development: An empirical investigation. American Economic Review, 91(5), 1369-1401.

Annen, K., \& , Knack, S. (2018). On the delegation of aid implementation to multilateral agencies. Journal of Development Economics, 133, 295-305.

Annen, K., \&, Knack, S. (2019). Better policies from policy-selective aid? World Bank Policy Research Working Paper 8889.

Bräutigam, D., \& Knack, S. (2004). Foreign aid, institutions, and governance in Sub-Saharan Africa. Economic Development and Cultural Change, 52(2), 255-285. 
Bulman, D., Kolkma, W., \& Kraay, A. (2017). Good countries or good projects? Comparing macro and micro correlates of World Bank and Asian Development Bank project performance. Review of International Organizations, 12(3), 335-363.

Carnegie, A. \& Dolan, L. (2021). The effects of rejecting aid on recipients' reputations: Evidence from natural disaster responses. Review of International Organizations, 16(3).

Clague, C., Keefer, P., Knack, S., \& Olson, M. (1999). Contract-intensive money: Contract enforcement, property rights, and economic performance. Journal of Economic Growth, 4(2), 185-211.

Coppedge, M., Gerring, J., Knutsen, C. H., Lindberg, S. I., Teorell, J., Alizada, N., Altman, D., Bernhard, M., Cornell, A., Fish, M. S., Gastaldi, L., Gjerløw, H., Glynn, A, Hicken, A., Hindle, G., Ilchenko, N., Krusell, J., Luhrmann, A., Maerz, S. F., Marquardt, K. L., McMann, K., Mechkova, V., Medzihorsky, J., Paxton, P., Pemstein, D., Pernes, J., von Römer, J., Seim, B., Sigman, R., Skaaning, S-E., Staton, J., Sundström, A., Tzelgov, E., Wang, Y., Wig, T., Wilson, S., \& Ziblatt, D. (2021). V-Dem [CountryYear/Country-Date] Dataset v11.1. Varieties of Democracy Project. https://doi.org/10.23696/vdems21

Dang, H.-A., Knack, S., \& Halsey Rogers, F. (2013). International aid and financial crises in donor countries. European Journal of Political Economy, 32(December), 232-250.

de la Cuesta, B., Milner, H. V., Nielson, D. L., \& Knack, S. (2019). Oil and aid revenue produce equal demands for accountability as taxes in Ghana and Uganda. Proceedings of the National Academy of Sciences of the United States of America, 116(36), 17717-17722.

de la Cuesta, B., Martin, L., Milner, H. V., \& Nielson, D. (2021). Foreign aid, oil revenues, and political accountability: Evidence from six experiments in Ghana and Uganda. Review of International Organizations, 16(3).

Denizer, C., Kaufmann, D., \& Kraay, A. (2013). Good countries or good projects? Macro and micro correlates of World Bank project performance. Journal of Development Economics, 105, 288-302.

Dreher, A., Simon, J., \& Valasek, J. (2021). Optimal decision rules in multilateral aid funds. Review of International Organizations, 16(3).

Eichenauer, V., \& Knack, S. F. (2018). Poverty and policy selectivity of World Bank trust funds. Journal of International Development, 30(4), 707-712.

Galiani, S., Knack, S., Xu, L. C., \& Zou, B. (2017). The effect of aid on growth: Evidence from a quasiexperiment. Journal of Economic Growth, 22, 1-33.

Gamso, J., Lu, J., \& Yuldashev, F. (2021). Does foreign aid volatility increase international migration? Review of International Organization, 16(3).

Gehring, K., Michaelowa, K., Dreher, A., \& Spörri, F. (2017). Aid fragmentation and effectiveness: What do we really know? World Development, 99, 320-334.

Gomez, B. T., Hansford, T. G., \& Krause, G. A. (2007). The Republicans should pray for rain: Weather, turnout, and voting in U.S. presidential elections. The Journal of Politics, 69(3), 649-663.

Hardin, G. (1968). The tragedy of the commons. Science, 162, 1243-1248.

Harris, J. (2021). Foreign aid, human capital accumulation and the potential implications for growth. Review of International Organization, 16(3).

Heckelman, J. C., \& Knack, S. (2009). Aid, economic freedom, and growth. Contemporary Economic Policy, 27(1), 46-53.

Heinzel, M., \& Liese, A. (2021). Managing performance and winning trust. How World Bank staff shape recipient performance. Review of International Organizations, 16(3).

Keefer, P. (2007). Clientelism, credibility, and the policy choices of young democracies. American Journal of Political Science, 51(4), 804-821.

Keefer, P., \& Knack, S. (1997). Why don't poor countries catch up? A cross-national test of an institutional explanation. Economic Inquiry, 35(3), 590-602.

Keefer, P., \& Knack, S. (2002). Polarization, politics and property rights: Links between inequality and growth. Public Choice, 111(1-2), 127-154.

Knack, S. (1992). Civic norms, social sanctions, and voter turnout. Rationality and Society, 4(2), 133-156.

Knack, S. (1993). The voter participation effects of selecting jurors from registration lists. The Journal of Law and Economics, 36(1), 99-114.

Knack, S. (1994). Does rain help the Republicans? Theory and evidence on turnout and the vote. Public Choice, 79, 187-209.

Knack, S. (1995). Does 'Motor Voter' work? Evidence from state-level data. The Journal of Politics, 57(3), 796-811.

Knack, S. (2001). Aid dependence and the quality of governance: Cross-country empirical tests. Southern Economic Journal, 68(2), 310-329.

Knack, S. (2004). Does foreign aid promote democracy? International Studies Quarterly, 48(1), 251-266. 
Knack, S. (2007). Measuring corruption: A critique of indicators in Eastern Europe and Central Asia. Journal of Public Policy, 27(3), 255-291.

Knack, S. (2009). Sovereign rents and quality of tax policy and administration. Journal of Comparative Economics, 37(3), 359-371.

Knack, S. (2013). Aid and donor trust in recipient country systems. Journal of Development Economics, 101, 316-329.

Knack, S. (2014). Building or bypassing recipient country systems: Are donors defying the Paris Convention? The Journal of Development Studies, 50(6), 839-854.

Knack, S., \& Keefer, P. (1995). Institutions and economic performance: Cross-country tests using alternative institutional measures. Economics and Politics, 7(3), 207-227.

Knack, S., \& Keefer, P. (1997). Does social capital have an economic payoff? A cross-country investigation. The Quarterly Journal of Economics, 112(4), 1251-1288.

Knack, S., \& Kropf, M. (2003). Voided ballots in the 1996 Presidential election: A county-level analysis. The Journal of Politics, 65(3), 881-897.

Knack, S., \& Rahman, A. (2007). Donor fragmentation and bureaucratic quality in aid recipients. Journal of Development Economics, 83(1), 176-197.

Knack, S., Rogers, F. H., \& Heckelman, J. C. (2012). Crossing the threshold: A positive analysis of IBRD graduation policy. Review of International Organizations, 7(2), 145-176.

Knack, S., \& Smets, L. (2013). Aid tying and donor fragmentation. World Development, 44, 63-76.

Knack, S., \& White, J. (2000). Election-day registration and turnout inequality. Political Behavior, 22(1), $29-44$.

Lang, V. (2021). The economics of the democratic deficit: The effect of IMF programs on inequality. Review of International Organizations, 16(3).

Langbein, L., \& Knack, S. (2010). The Worldwide Governance Indicators: Six, one or none? The Journal of Development Studies, 46(2), 350-370.

Marchesi, S., \& Masi, T. (2021). Delegation of implementation in project aid. Review of International Organization, 16(3).

North, D. C. (1981). Structure and change in economic history. Norton.

North, D. C. (1990). Institutions, institutional change and economic performance. Cambridge University Press.

Olson, M. (1965). The logic of collective action: Public goods and the theory of groups. Harvard University Press.

Olson, M. (1982). The rise and decline of nations: Economic growth, stagflation, and social rigidities. Yale University Press.

Ostrom, E. (1990). Governing the commons: The evolution of institutions for collective action. Cambridge University Press.

Paxton, P., \& Knack, S. (2012). Individual and country-level factors affecting support for foreign aid. International Political Science Review, 33(2), 171-192.

Putnam, R. D., \& with Leonardi, R., \& Nonetti, R. Y. . (1993). Making democracy work: Civic traditions in modern Italy. Princeton University Press.

Reinsberg, B., Michaelowa, K., \& Knack, S. (2017). Which donors, which funds? Bilateral donors' choice of multilateral funds at the World Bank. International Organization, 7(4), 767-802.

Smets, L., \& Knack, S. (2016). World Bank lending and the quality of economic policy. Journal of Development Studies, 52(1), 72-91.

Smets, L., Knack, S., \& Molenaers, N. (2013). Political ideology, quality at entry and the success of economic reform programs. Review of International Organizations, 8(4), 447-476.

Tendler, J. (1975). Inside foreign aid. Johns Hopkins University Press.

Vreeland, J. R. (2002). The effect of IMF programs on labor. World Development, 30(1), 121-139.

Williams, A. (2015). A global index of information transparency and accountability. Journal of Comparative Economics, 43(3), 804-824.

Zak, P. J., \& Knack, S. (2001). Trust and growth. The Economic Journal, 111(470), 295-321.

Publisher's Note Springer Nature remains neutral with regard to jurisdictional claims in published maps and institutional affiliations. 